Hanaa El-Karaksy • Nehal El-Koofy • Manal El-Hawary • Azza Mostafa • Mona Aziz • Mortada El-Shabrawi • Nabil A. Mohsen - Magd Kotb • Mona El-Raziky • Marwa Abu El-Sonoon · Hassan A-Kader

\title{
Prevalence of factor V Leiden mutation and other hereditary thrombophilic factors in Egyptian children with portal vein thrombosis: results of a single-center case-control study
}

Published online: 14 December 2004

C) Springer-Verlag 2004

\section{Ann Hematol (2004) 83:712-715}

Due to a technical mistake, the end of the reference list was cut off. The entire list should have been as follows:

\section{References}

1. Yamada R, Antunes M, Cardoso S, Servidoni M, Hessel G (1999) Portal vein thrombosis in children: clinical and laboratory study of 26 cases. Arq Gastroenterol 36:49-53

2. Rosendaal FR (1997) Thrombosis in the young: epidemiology and risk factors. A focus on venous thrombosis. Thromb Haemost 78:1-6

3. Kim J, Lee Y, Kim S, Lee S, Lim M, Kim H (2001) Does umbilical vein catheterization lead to portal vein thrombosis? Prospective evaluation in 100 neonates. Radiology 219:645650

4. Gurgey A, Aslan D (2001) Outcome of non-catheter related thrombosis in children: influence of underlying or co-existing factors. J Pediatr Hematol Oncol 23:159-164

5. Ahuja V, Marwaha N, Chawla Y, Dilawari JB (1999) Coagulation abnormalities in idiopathic portal vein thrombosis. J Gastroenterol Hepatol 14:1210-1211

The online version of the original article can be found at http://dx. doi.org/10.1007/s00277-004-0921-4

H. El-Karaksy $(\bowtie) \cdot$ N. El-Koofy $\cdot$ M. El-Hawary ·

M. El-Shabrawi - N. A. Mohsen - M. Kotb - M. El-Raziky ·

M. A. El-Sonoon

Department of Pediatrics, Faculty of Medicine, Cairo

University,

Cairo, Egypt

e-mail: hanaakaraksy@hotmail.com

Fax: +20-2-5311616

\section{A. Mostafa - M. Aziz}

Department of Clinical Pathology, Faculty of Medicine, Cairo University,

Cairo, Egypt

H. A-Kader

Department of Pediatrics, The University of Arizona,

Tuscon, USA
6. Voelkerding KY, Hither S, Strobl F, Wit LA, Sebastinin LV, Anderson M, Lutz CT (1996) Resistance to activated protein C: comparison of the three different PCR methods for detection of FV R506Q. Mol Diagn 1:297-304

7. Yachha SK, Srivastava A, Sharma BC, Khanduri A, Baijjal SS (1996) Therapeutic gastrointestinal endoscopy. Indian J Pediatr 63:633-639

8. Pinar A, Saenz R, Rebollo J, Gomez-Parra M, Carrasco F, Herrerias JM, Jimenez-Saenz M (1998) Portal and mesenteric vein thrombosis in a patient heterozygous for a mutation (Arg506-Gln) in the factor $\mathrm{V}$ gene (factor V Leiden). J Clin Gastroenterol 27:361-363

9. Chamouard P, Pencreach E, Maloisel F, Grunebaum L, Ardizzone JF, Meyer A, Gaub MP, Goetz J, Baumann R, Uring-Lambert B, Levy S, Dufour P, Hauptmann G, Oudet P (1999) Frequent factor II G20210A mutation in idiopathic portal vein thrombosis. Gastroenterology 116:144-148

10. Bombeli T, Basic A, Fehr J (2002) Prevalence of hereditary thrombophilia in patients with thrombosis in different venous systems. Am J Hematol 70:126-132

11. Heller C, Schobess R, Kurnik K, Junker R, Gunther G, Kreuz W, Nowak-Gottl U (2000) Abdominal venous thrombosis in neonates and infants: role of prothrombotic risk factors-a multicenter case-control study. For the Childhood Thrombophilia Study Group. Br J Haematol 111:534-539

12. Egesel T, Buyukasik Y, Dundar SV, Gurgey A, Kirazli S, Bayraktar Y (2000) The role of natural anticoagulant deficiencies and factor $\mathrm{V}$ Leiden in the development of idiopathic portal vein thrombosis. J Clin Gastroenterol 30:6671

13. Fisher NC, Wilde JT, Roper J, Elias E (2000) Deficiency of natural anticoagulant proteins $\mathrm{C}, \mathrm{S}$ and antithrombin III in portal vein thrombosis: a secondary phenomenon? Gut 46:534 539

14. Schobess R, Junker R, Auberger K, Munchow N, Burdach S, Nowak-Gottl U (1999) Factor V G1691A and prothrombin G20210A in childhood spontaneous venous thrombosis-evidence of an age-dependant thrombotic onset in carriers of factor V G1691A and prothrombin G20210A mutation. Eur J Pediatr 158 [Suppl 3]:S105-S108

15. Janssen HL, Meinardi JR, Vleggaard FP, Van Uum SH, Haagsma EB, van Der Meer FJ, van Hattum J, Chamuleau RA, Adang RP, Vandenbroucke JP, van Hoek B, Rosendaal FR (2000) Factor V Leiden mutation, prothrombin gene mutation, and deficiencies in coagulation inhibitors associated with Budd-Chiari syndrome and portal vein thrombosis: results of a case-control study. Blood 96:2364-2368 